\title{
PENCIPTAAN FILM FIKSI “DIBALIK SUNGAI ULAR” MENGGUNAKAN ALUR NON-LINEAR
}

\author{
Sri Wahyuni ${ }^{*}$, Surya Darma ${ }^{2 *}$, Saaduddin $^{3^{*}}$ \\ Fakultas Seni dan Desain ${ }^{1 * 2 *}$ \\ Universitas Potensi Utama ${ }^{1 * 2 *}$ \\ Jl. KL Yos Sudarso Km. 6.5, No. 3A, Tanjung Mulia, Kec. Medan Deli, Kota Medan, Kode Pos 20241 \\ Sumatera Utara. Indonesia \\ Fakultas Seni Pertunjukan ${ }^{3 *}$ \\ Institut Seni Indonesia Padangpanjang ${ }^{3 *}$ \\ Jl. Bahder Johan, Guguak Malintang, Padangpanjang, Kota Padangpanjang, Kode Pos 27126 \\ Sumatera Barat. Indonesia \\ Email: sriwahyuni2909@gmail.com,suryadarma766@gmail.com,hanyadidin@gmail.com
}

\begin{abstract}
Abstrak
Film fiksi "Dibalik Sungai Ular" disajikan dengan mengusung tema tentang seorang anak kecil dan keluarganya. Sebagai karakter utama yang polos dapat menjangkau emosi terdalam, maka hubungan antar tokoh sebagai penggerak alur menjadi fokus film ini dengan penerapan alur nonlinear dalam penyutradaraan. Pola ini memanipulasi urutan waktu kejadian dengan mengubah urutan plotnya sehingga membuat hubungan kausalitas menjadi tidak jelas. Tujuan digunakannya pendekatan alur nonlinear agar menarik mata penonton untuk tetap menyaksikan film ini hingga selesai. Metode yang digunakan dalam penciptaan film "Dibalik Sungai Ular" yaitu dimulai dari Pra Produksi yang dimulai dari (pengembangan ide/gagasan, pengumpulan data dari hasil studi pustaka, wawancara, observasi, dokumentasi, produksi film dan pasca-produksi (editing/finishing). Hasil penerapan alur nonlinear pada film "Dibalik Sungai Ular" berada pada seluruh aspek pembentuk film mulai dari naratif (naskah), sinematik (penggunaan kamera handheald), mise-en-scene (latar, kostum dan makeup, pencahayaan dan pemain dan pergerakannya) hingga proses penyuntingan yang menggunakan metode jump cut. Penggunaan pendekatan alur nonlinear menjadikan tontonan yang menarik dan memaksa penonton untuk mengikuti film hingga akhir.
\end{abstract}

Kata Kunci: film fiksi, metode, penonton.

\begin{abstract}
The fictional film "Behind the Snake River" is presented with a small child and his family's theme. As the main character who is innocent can reach the deepest emotions, the relationship between the characters as the driving force of the plot becomes the focus of this film with the application of a nonlinear plot in directing. This pattern manipulates the time sequence of events by changing the sequence of the plots so that the causality relationship is unclear. The purpose of using a non-linear plot approach is to attract the eye of the audience to continue watching this film until it's finished. The method used in the creation of the film "Behind the Snake River" starts with Pre Production starting from (developing ideas/ideas, collecting data from literature studies, interviews, observation, documentation, film production and post-production (editing/finishing). The results of the application of the non-linear plot in the film "Behind the Snake River" are in all aspects of the film-forming from the narrative (script), cinematic (use of handheld cameras), mise-en-scene (background, costumes, and makeup, lighting and actors and movements) to the editing process uses the jump cut method The use of a non-linear plot approach makes the spectacle interesting and forces the audience to follow the film until the end.
\end{abstract}

Keywords: fiction film, method, audience.

\section{PENDAHULUAN}

Sungai Ular merupakan sungai yang terletak pada Jl. Medan - Tebing Tinggi, Simpang Tiga Pekan, Kec. Perbaungan, Kabupaten Serdang Bedagai. Tepatnya terletak diperbatasan antara Deli Serdang dan Serdang
Bedagai dan memiliki panjang kurang lebih $45 \mathrm{Km}$. Selain itu, sungai ular memiliki nama yang unik karena dianggap bahwa sungai tersebut memiliki banyak ular atau panjang sungai tersebut seperti ular. 
Legenda Sungai Ular yang berada tepat diperbatasan antara Kabupaten Serdang Bedagai dan Kabupaten Deli Serdang. Menurut penuturan masyarakat, konon katanya sungai ini terbentuk akibat sebuah lintasan dari seekor ular besar yang menuju ke laut dan hasil dari tapak ular tersebut terbentuklah sungai yang apabila dilihat dari atas mirip dengan liukan ular sehingga disebut masyarakat dengan sungai ular. Masyarakat juga percaya bahwa di sungai tersebut banyak ular sehingga masyarakat tidak pernah masuk ke dalam sungai tersebut karena takut gigitan ular yang berada di sungai tersebut (Mawar Kembaren et al., 2020).

Berangkat dari latar belakang sungai ular tersebut menjadi sebuah inspirasi dan ide yang menarik untuk selanjutnya di angkat menjadi sebuah film fiksi "Dibalik Sungai Ular". Yang mana sungai ular sendiri menjadi salah satu lokasi syuting dalam Penciptaan karya film fiksi "Dibalik Sungai Ular". Film Dibalik Sungai Ular mengusung tema anak kecil dan keluarga. Yang menceritakan mengenai seorang anak kecil sebagai tokoh utama di sebuah desa sangat menyukai bermain di sungai selayaknya seperti anak-anak yang lain.

Akan tetapi, anak tersebut selalu dilarang oleh ayah dan ibunya karena suatu hal yang tidak diketahui anak tersebut. Bagaimana seorang anak yang memiliki sifat alamiah polos bertanya-tanya kenapa dirinya dilarang di bermain disungai hingga membuatnya bingung dan ingin mencari tau. Kemudian peran seorang anak kecil tersebut sebagai karakter utama yang dapat menjangkau emosi terdalam dari keluarganya di dalam film "Dibalik Sungai Ular". Hubungan kausalitas dapat saling mempengaruhi dalam kehidupan seseorang. Faktor penyebab mengapa keluarga sangat melarang anaknya bermain di sungai tentunya memiliki alasan yaitu berlandaskan masa lalu dari Ayah anak tersebut yang berkaitan dengan sejarah sungai ular sendiri yaitu pembantaian Partai Komunis Indonesia (PKI).

\section{KAJIAN TEORI}

\section{Pengertian Film}

Film diartikan sebagai hasil budaya dan alat ekspresi kesenian. Film sendiri secara umum dapat dibagi menjadi 2 unsur pembentuk yaitu unsur naratif dan unsur sinematik. Dua unsur tersebut dapat saling berinteraksi dan berkesinambungan satu dengan lainnya yang kemudian membentuk sebuah film. Film tidak akan terbentuk jika hanya menggunakan satu unsur saja atau berdiri sendiri. Jadi, bisa dikatakan bahwa unsur merupakan bahan materi yang dapat/akan diolah sedangkan unsur sinematik adalah cara (gaya) untuk mengolahnya. Dalam film cerita unsur naratif adalah perlakuan terhadap cerita filmnya. Sementara unsur sinematik atau juga sering diistilahkan dengan gaya sinematik terbagi menjadi empat elemen pokok yaitu mise-en-scene, sinematografi, editing dan suara. Masing-masing elemen sinematik tersebut juga saling berinteraksi dan berkesinambungan satu dengan yang lainnya hingga membentuk sebuah film yang utuh (Pratista, 2008: 1-2). Kedua unsur tersebut dirasa sangat lengkap dalam memproduksi film "Dibalik Sungai Ular" ini. Seorang sutradara dapat mengembangkan kedua unsur tersebut untuk menghasilkan film yang baik.

\section{Pengertian Alur Non-Linear}

Konsep penyutradaraan yang digunakan dalam film "Dibalik Sungai Ular" yaitu alur non-linear yang merupakan pola urutan waktu plot yang jarang digunakan dalam film cerita. Pola ini memanipulasi urutan waktu kejadian dengan mengubah urutan plotnya sehingga membuat hubungan kausalitas menjadi tidak jelas. Pola non-linear cenderung menyulitkan penonton untuk bisa mengikuti alur cerita filmnya. Satu contoh, jika urutan waktu cerita dianggap A-B-C-D-E maka urutan waktu plotnya dapat C-D-EA-B atau D-B-C-A-E atau lainnya. Jika cerita film berlangsung selama sehari, maka penutupan kisahnya disajikan secara tidak urut, misalkan malam, pagi, sore dan siang. Tentu saja pola seperti ini akan menyulitkan penonton untuk memahami ceritanya (Pratista, 2008: 37).

Alur non-linear tersebut alur yang jarang digunakan dalam pembuatan sebuah karya film, dikarenakan alurnya yang tidak runtut, plot yang dibongkar susunannya membuat bingung penonton terlebih pada babak awal pengenalan dalam film. Sehingga film -film dengan alur seperti ini mengharuskan penonton menyaksikan hingga akhir cerita, agar dapat benarbenar memahami apa yang sedang terjadi pada tokoh utama dalam cerita yang disajikan. Cerita film pada umumnya menampilkan aksi-reaksi, namun teknik ini melibatkanya menjadi reaksi-aksi. Sejak awal cerita, penonton disajikan sebuah peristiwa secara terbalik dan kemudian bertutur mundur menjelaskan latar belakang peristiwa tersebut (Pratista, 2008: 37).

Proses pengerjaan karya dengan menggunakan alur non-linear mengacu kepada naskah "Dibalik Sungai Ular" yang telah memiliki alur non-linear. Dari naskah tersebut telah dirincikan segala komponenkomponen gambar yang dibutuhkan sesuai rangkaian cerita. Mulai dari pra produksi, produksi hingga paska produksi. Untuk membuat karya dengan alur nonlinear, dibutuhkan penggarapan yang detail dalam 
mempertegas perbedaan waktu. Di karenakan pola yang tidak urut, tentu terdapat bagian-bagian flashback. Adegan flashback tersebut haruslah memiliki perbedaan dari segala sisi, mulai dari mise-enscene, sinematografi dan lain sebagainya yang dapat membedakan waktu kejadian. Hal ini digunakan agar penonton tidak terlalu bingung menyimak apa yang sedang terjadi atau disuguhkan dalam sebuah karya film Melalui dialog percakapan antara dua orang yaitu seorang anak kecil sebagai tokoh utama dan keluarga (ibu) nya, yang mana dalam dialog tersebut akan diselipkan adegan flashback dari cerita yang disampaikan oleh ibunya untuk memperkuat nilai dramatik dari cerita yang disajikan. Penggunaan alur tersebut untuk memanipulasi kronologi plot pada film fiksi "Dibalik Sungai Ular" serta bertujuan untuk menyampaikan informasi cerita secara perlahan dan sedikit membingungkan para penonton sehingga memaksa penonton untuk menonton film hingga selesai.

\section{METODE PENELITIAN}

Metode merupakan sebuah cara kerja yang dilakukan pengkarya seni dalam mentransformasikan ide dan gagasan dalam menciptakan sebuah karya seni. Fenomena ini akan diaplikasikan ke dalam bentuk karya film fiksi.

Metode pada dasarnya merupakan cara untuk mendapatkan data dengan tujuan dan kegunaan tertentu (Sugiono, 2011:2). Sedangkan dalam kamus Besar Bahasa Indonesia, penciptaan berasal dari kata "cipta yaitu kemampuan pikiran untuk mengadakan sesuatu yang baru, angan-angan yang kreatif. "Menciptakan" berarti menjadikan sesuatu yang baru, membuat sesuatu yang baru (belum pernah ada), membuat suatu hasil kesenian. Jadi penciptaan adalah proses, cara perbuatan menciptakan. Maka, metode penciptaan merupakan cara menciptakan suatu yang baru untuk mendapatkan hasil karya dengan tujuan dan kegunaan tertentu (Sugiharti, 2016). Metode yang digunakan dalam penciptaan film "Dibalik Sungai Ular" yaitu Pra Produksi yang dimulai dari [1] pengembangan ide/gagasan berdasarkan dari sejarah sungai ular tersebut yang kemudian di refleksikan menjadi sebuah karya film fiksi; [2] Penulis melakukan pengumpulan data dari hasil studi pustaka, dengan menggali informasi mengenai sungai ular dan teknik alur non-linear yang digunakan. Bagaimana penerapan teknik alur nonlinear dengan cerita yang dibangun; [3] Selanjutnya melakukan observasi pada beberapa lokasi termasuk sungai ular, [4] serta melakukan dokumentasi.
Selanjutnya Melakukan produksi film dan pascaproduksi (editing/finishing).

Penulis juga merujuk beberapa penelitian terdahulu terkait penciptaan film "Dibalik Sungai Ular" seperti penelitian (Andhika, 2018) dalam jurnal Ekspresi Seni yang berjudul "Film Bagurau; Representasi Perempuan Minangkabau" merupakan film pendek yang mengangkat tentang isu sosial mengenai perempuan Minangkabau melalui sudut pandang tukang dendang dalam pertunjukan musik malam Bagurau. Selanjutnya penelitian (Si et al., 2017) dalam skripsi yang berjudul "Penyutradaraan Film Fiksi "Toilet" Menggunakan Alur Non-Linear" menjelaskan konflik yang ada pada mahasiswa tingkat akhir pada sebuah perguruan tinggi, yang mana cerita tersebut dikemas menggunakan alun nonlinear sehingga penonton akan menebak-nebak ketika menonton film tersebut.

Kemudian penelitian (Ediantes, 2015) dalam jurnal Ekspresi Seni yang berjudul "Ritual sebagai Sumber Penciptaan Film Basafa di Ulakan yang membahas tentang penciptaan film dokumenter mengangkat sebuah ritual keagamaan yang dilaksanakan oleh para pengikut tarekat Syatariah bersifat Sufisme, dimana ritual tersebut memiliki alasan-alasan tertentu yang sulit dipahami. Penelitian ini menjelaskan bagaimana sutradara menginterpretasikan ritual tersebut ke dalam sebuah film dokumenter.

\section{HASIL DAN PEMBAHASAN}

\section{Hasil}

Hasil penelitian ini memusatkan pada luaran berupa penciptaan sebuah film fiksi yang berangkat dari legenda Sungai Ular yang berada tepat diperbatasan antara Kabupaten Serdang Bedagai dan Kabupaten Deli Serdang. Emphasis terhadap peristiwa yang terjadi mengenai Sungai Ular tersebut penulis interpretasikan lewat sebuah film fiksi yang memuat kisah tentang mitos berupa larangan-larangan dalam kehidupan yang dialami anak-anak yang diwujudkan dalam tokoh Anak.

\section{Pembahasan}

Interpretasi terhadap riset yang dilakukan membuat penulis melakukan beberapa tahapan penciptaan film fiksi menggunakan alur non-linear. Alur ini digunakan sebagai pilihan untuk membuat film ini memiliki gaya dalam menyampaikan pesan kepada audiens. Pada pembahasan ini Sutradara memiliki peran sangat penting dalam menerapkan teknik alur non-linear mulai dari proses pembuatan naskah, memahami naskah hingga masuk bedah naskah sehingga terbentuk pola alur non-linear tersebut. 


\section{1). Ide Penciptaan}

Sungai Ular memiliki banyak cerita-cerita mitos dan memiliki sejarah. Mitos yang berkembang mengenai sungai ular yaitu sungai ular dipercaya dihuni oleh sepasang buaya putih yang dapat merubah wujudnya menjadi manusia dan siap mencari mangsa dan menerkamnya. Selain itu, sungai ular memiliki cerita sejarah mengenai penjagalan para PKI atau sebagai salah satu lokasi perkuburan masal para PKI.

Berangkat dari cerita di atas, sungai ular sangat menarik untuk di angkat menjadi sebuah film fiksi. Meskipun sungai ular memiliki cerita mitos dan sejarah dimasa lampau, namun film fiksi “ Dibalik Sungai Ular” tidak menceritakan secara spesifik sejarah-sejarah ataupun mitos tersebut.

Dalam artiannya, proses penciptaan film ini merupakan proses memahami ulang sebuah mitos. Proses defenisi ulang terhadap kebudayaan yang dapat membentuk iklim kreatifitas masyarakat pendukungnya, bahwa memahami kebudayaan harus dimulai dengan mendefinisikan ulang kebudayaan itu sendiri, bukan sebagai kebudayaan generic (yang merupakan pedoman yang diturunkan) tetapi sebagai kebudayaan diferensial (yang dinegosiasikan dalam keseluruhan interaksi sosial). Kebudayaan bukanlah suatu warisan yang secara turun temurun dibagi bersama atau dipraktikkan secara kolektif, tetapi menjadi kebudayaan yang lebih bersifat situasional yang keberadaannya tergantung pada karakter kekuasaan dan hubungan-hubungan yang berubah dari waktu ke waktu (Pertiwi \& Yusril, 2019).

Pada proses ini penulis menyajikan film tersebut dengan versi yang berbeda yaitu dengan mengusung tema tentang seorang anak kecil dan Keluarganya. Seorang anak kecil di sebuah desa yang sangat suka bermain di sungai selayaknya seperti anak-anak yang lain. Tetapi dilarang oleh keluarganya karena suatu hal yang tidak diketahui anak tersebut. Bagaimana peran seorang anak kecil sebagai karakter utama yang polos dapat menjangkau emosi terdalam dari keluarganya didalam film "Dibalik Sungai Ular".

Hubungan kausalitas dapat saling mempengaruhi dalam kehidupan seseorang. Faktor penyebab mengapa keluarga sangat melarang anaknya bermain di sungai tentunya memiliki alasan tersendiri dari keluarganya.

Adapun sinopsis film "Dibalik Sungai Ular sebagai berikut:
Inur (6) Seorang anak perempuan yang sangat suka bermain di Sungai ular tanpa batasan waktu. Inur merupakan anak tunggal dari keluarga sederhana di desa yang berada di Serdang Bedagai. Inur menjalani hari-harinya dengan sekolah, bermain dan membantu ibu nya mencari kayu sebagai bahan bakar untuk memasak dirumahnya. Inur sering mencari kayu bakar sambil bermain ke sungai ular. Namun, entah mengapa, tiba-tiba ibunya melarangnya untuk bermain ke sungai lagi tanpa tau apa penyebab dilarangnya Inur mandi disungai. Inur pun memutar ingatannya mencari jawaban dan bertanya-tanya apa penyebab dilarang bermain ke sungai lagi oleh orang tuanya. Inur terlihat murung dan seperti tidak bergairah ingin bermain. Disisi lain, Orang tua Inur merasa kasihan dengan anaknya tetapi mereka tidak ingin anaknya mengetahui alasan sebenarnya dan berniat menyembunyikannya.

\section{2). Konsep Penyutradaraan}

Alur non-linear merupakan alur yang tidak banyak digunakan dalam pembuatan sebuah film. Selain alurnya yang tidak runtut sering kali juga membuat penonton merasa bingung ketika menyaksikan film tersebut terlebih pada saat pengenalan tokoh dalam cerita. Menurut Hilmawan Pratista:

Non-linear adalah pola urutan waktu plot yang jarang digunakan dalam film cerita. Pola ini memanipulasi urutan waktu kejadian dengan mengubah urutan plotnya sehingga membuat hubungan kausalitas menjadi tidak jelas. Pola non-linear cenderung menyulitkan penonton untuk bisa mengikuti alur cerita filmnya. Satu contoh, jika urutan cerita dianggap A-B-C-D-E maka urutan waktu plotnya dapat C-DE-A-B atau D-B-C-A-E atau lainnya. (Pratista 2008: 37).

Pola alur non-linear dalam cerita film biasanya akan menampilkan reaksi-aksi. Hal ini akan menyulitkan penonton yang pada umumnya menampilkan aksireaksi namun pada pola ini sebaliknya. Penonton dari awal akan disajikan dengan peristiwa secara mundur dalam menjelaskan latar belakang film tersebut (Pratista, 2008: 37). Proses pengerjaan karya mengacu kepada naskah yang sudah dirancang dengan konsep alur non-linear. Selanjutnya dirincikannya melalui komponen visual / gambar yang meliputi pra produksi, produksi serta pasca produksi.

Penggarapan film "Dibalik Sungai Ular" dibuat lebih rinci dalam mempertegas ruang dan waktu yang digunakan. Hal ini, karena dalam film "Dibalik Sungai Ular" terdapat adegan flashback dibagian-bagian tertentu sesuai dengan alur non-linear tersebut. Adegan 
Flashback tersebut tentunya memiliki perbedaan baik dari sisi sinematografi, mise-en-scene dan sisi lainnya. Hal ini digunakan agar visual yang ditampilkan dapat dibedakan ruang dan waktunya sehingga penonton tidak terlalu bingung dengan film yang disuguhkan.

Sutradara memiliki tanggung jawab yang sangat besar dalam pengaplikasian teoritis. Melalui konsep penyutradaraan yang telah disusun dan dibuat secara rinci dalam sebuah naskah "Dibalik Sungai Ular". Selain itu, Alur non-linear dapat dilihat dari aspek visual dan lainnya seperti sinematografi dan mise-enscene yang akan dibahas selanjutnya.

\section{3). Sinematografi}

Penggunaan alur non-linear dalam film "Dibalik Sungai Ular" tidak terlepas dengan teknik sinematografi untuk melihat perbedaan waktu dalam mempertegas alur yang dibuat tidak urut.

Sinematografi dalam setiap shot yang diambil oleh kamera juga sangat diperhatikan. Fillmmaker tidak hanya berbicara tentang film apa yang dibuat tetapi bagaimana seorang filmmaker membuat film. Sehingga, sinematografi pada setiap shot film sangat diperhatikan (Darmawan \& Pramayoza, 2020). Selain itu, seluruh scene pada film ini menggunakan teknik kamera handheld untuk menghidupkan aspek visual / gambar dalam cerita film. Pengambilan gambar yang di lakukan pada bagian awal cerita dilakukan secara objektif dengan memberikan penegasan dalam ekspresi tokoh utama sebagai penggerak cerita. Penonton akan menduga-duga apa yang akan terjadi dalam cerita selanjutnya.

Selain itu film "Dibalik Sungai Ular" menggunakan beberapa angle camera, salah satunya seperti penggunaan medium close up untuk menampilkan beberapa ekspresi tokoh utama yang terlihat polos ketika sedang menebak-nebak mengenai perubahan sikap ibunya yang tiba-tiba melarangnya pergi ke sungai.

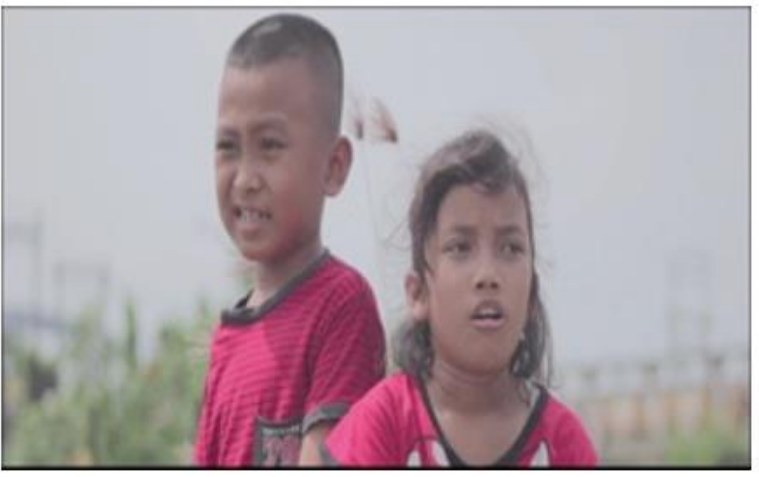

Gambar 1. Inur Sedang Bercerita dengan Temannya (Pratista, 2008)

Dalam beberapa bagian, penggunaan high angle juga digunakan untuk memberikan kesan kedalaman dengan tokoh atas pertimbangan adegan dan setting yang digunakan. Pencapaian melalui angle ini berfungsi untuk memberikan keterkaitan tokoh utama dengan subjek sekitar yang berada dalam frame. Pergerakan kamera track in akan membantu memberikan kesan suspence sehingga penonton dapat merasakan dramatik melalui pemilihan angleangle tersebut.

\section{4). Mise-En-Scene}

(Alfathoni, 2019) pada jurnal Proposi yang berjudul "Mise en Scene dalam Film Lamaran Sutradara Monty Tiwa" menjelaskan bahwa mise en scene merupakan elemen sinematik yang sangat penting yang terdapat pada unsur film. Kesan dramatis pada film dapat direalisasikan pada penonton dengan baik melalui unsur tersebut. Para sineas harus merancang mise en scene secara matang ketika ingin memproduksi sebuah film. Hal ini sejalan dengan film "Dibalik Sungai Ular" yang mengkonsep secara matang penggunaan mise en scene dan lainnya pada saat sebelum dilakukannya produksi. Penerapan mise en scene tentunya disesuaikan dengan alur naskah yang sudah di buat secara detail dengan alur non-linear sehingga mise en scene yang digunakan dapat membantu mempertegas cerita pada film "Dibalik Sungai Ular". Mise en scene merupakan unsur pendukung dalam sebuah film yang memegang peran yang sangat penting untuk mempertegas alur sebuah film yang tentunya membawa kekuatan dalam film tersebut. Mise en scene dalam sebuah film terbagi atas empat bagian sebagai berikut: 

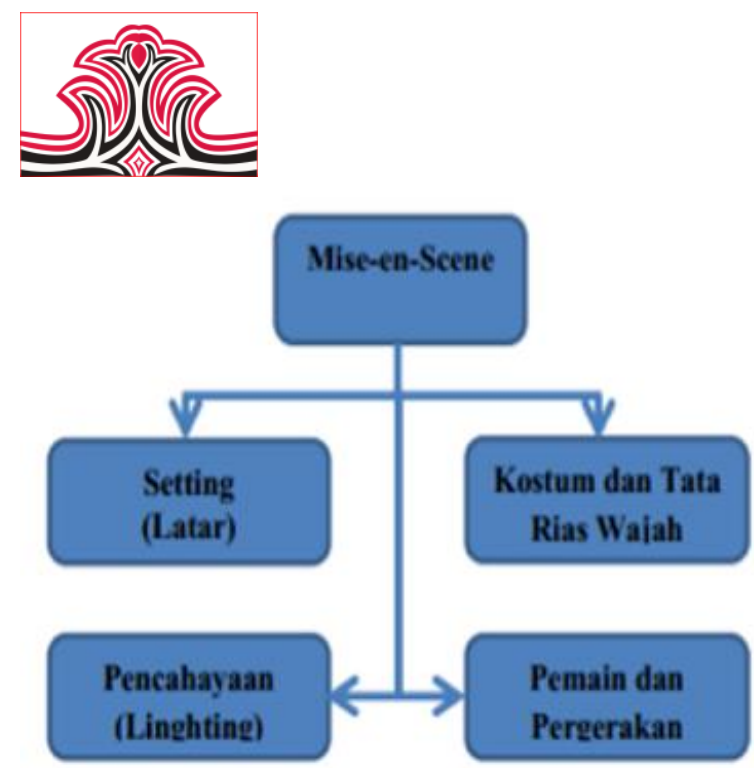

Gambar 2. Aspek Mise En Scene (Pratista, 2008)

Menurut Pratista (2008: 71) Aspek mise en scene menjelaskan rangkaian yang terdapat pada aspek visual tersebut seperti [1] Setting (latar) dalam stuktur mise en scene berkaitan dengan semua properti yang terdapat di dalam sebuah film terkait ruang dan waktu yang ditampilkan dalam sebuah film; [2] Kostum dan tata rias wajah merupakan semua unsur yang digunakan aktor/aktris termasuk aksesoris pada saat proses syuting berlangsung. Kostum tersebut memiliki fungsi yang sama dengan latar yaitu sebagai penunjuk ruang dan waktu, status sosial, kepribadian. Selain itu, warna kostum juga memiliki makna sebagai simbol atau penggerak sebuah cerita film;

[3] pencahayaan merupakan unsur yang paling penting dalam memproduksi sebuah film. Tanpa adanya cahaya maka penonton hanya akan melihat kegelapan saja. Pencahayaan bahakan dapat membentuk mood dalam sebuat film. Cahaya dalam pembuatan film berfungsi untuk memanipulasi setiap gambar yang ada disetiap adegan film yang menyangkut kualitas, arah, sumber, dan warna; [4] Aktor dan pergerakannya merupakan unsur yang dapat memotivasi setiap unsur naratif dalam cerita film. Seorang aktor di tuntut untuk mampu melakukan pergerakan cerita film sesuai dengan naskah yang dibangun agar aspek dramatis dapat tersampaikan pada penonton. Adapun aspek mise en scene pada film "Dibalik Sungai Ular" akan dijelaskan lebih lanjut sebagai berikut:

\section{(1). Latar}

Latar merupakan bagian dari mise-en-scene yang sangat berhubungan erat dengan aspek visual yang dibutuhkan untuk menjelaskan asek ruang dan waktu. Latar pada film "Dibalik Sungai Ular" mengacu pada naskah yang sudah dirincikan dengan konsep alur nonlinear berdasarkan hasil observasi yang di lakukan
Gorga : Jurnal Seni Rupa

Volume 10 Nomor 01 Januari-Juni 2021

p-ISSN: 2301-5942 | e-ISSN: 2580-2380

sebelumnya. Film "Dibalik Sungai Ular" menggunakan beberapa latar seperti lokasi utama yaitu sungai ular sendiri. Adapun gambaran sungai ular dalam film sebagai berikut:

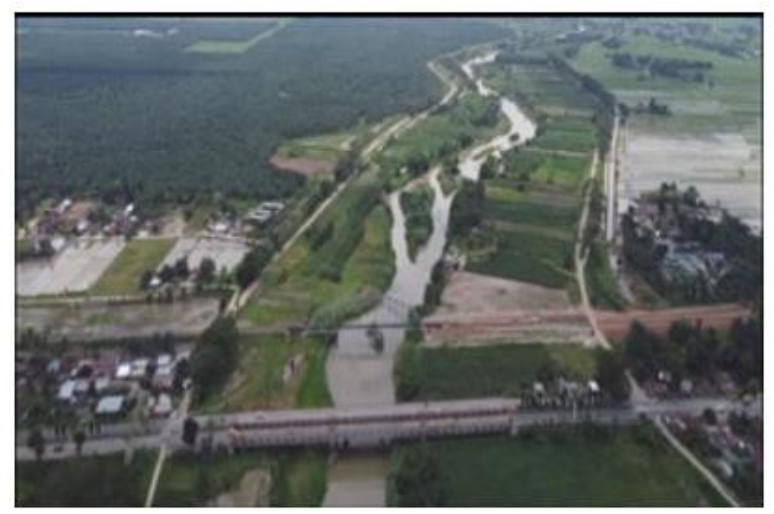

Gambar 3. Lokasi Sungai Ular (Screenshot Film "Dibalik Sungai Ular") (Wahyuni, 2020)

Selain itu, lokasi-lokasi lain juga turut mendukung dalam pembentukan latar pada film seperti pada adegan flashback Inur ketika berusaha mengingat kenapa ibu nya tiba-tiba melarangnya untuk pergi ke sungai lagi. Lokasi adegan flashback tersebut berada di sebuah hutan ketika Inur mencari kayu bakar bersama ibunya. Lokasi tersebut dapat dilihat pada gambar di bawah ini:

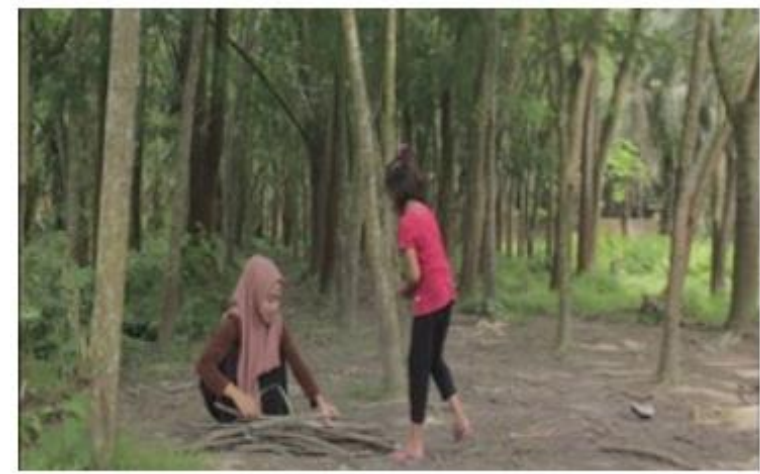

Gambar 4. Lokasi Hutan ketika Mencari Kayu Bakar (Screenshot Film "Dibalik Sungai Ular") (Wahyuni, 2020)

Kemudian rumah juga digunakan sebagai salah satu lokasi yang menjadi ciri dari kehidupan Inur dan keluarganya. Rumah tersebut menggambarkan kesederhanaan kehidupan Inur yang berasal dari keluarga kalangan bawah bertempat tinggal di Serdang Bedagai dekat dengan Sungai Ular sendiri. Berikut merupakan gambaran dari rumah Inur dan keluarganya: 


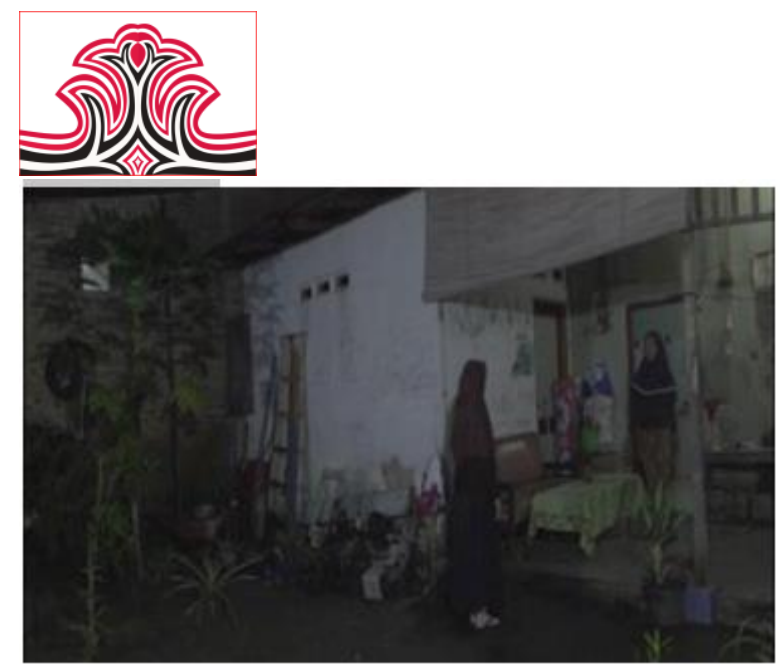

Gambar 5. Rumah Inur

(Screenshot Film "Dibalik Sungai Ular")

(Wahyuni, 2020)

Berdasarkan gambar 1, gambar 2 dan gambar 3 merupakan cuplikan latar yang terdapat pada film "Dibalik Sungai Ular". Begitu juga dengan scene-scene yang lain yang disesuaikan dengan kebutuhan naskah yang sudah dibuat.

\section{(2). Kostum dan Make-Up}

Kostum yang digunakan dalam pemeran pada film "Dibalik Sungai Ular" disesuaikan dengan masyarakat Serdang Bedagai - kota Medan. Selain itu, juga disesuaikan dari kehidupan Inur dan keluarganya yang berasal dari keluarga sederhana dengan menggunakan pakaian-pakaian sederhana seperti kaos oblong, celana pendek, sendal jepit dan pakaian sehari-hari lainnya. Properti yang lain juga minim digunakan karena memang ingin menggambarkan keluarga yang sederhana sehingga tidak banyak peroperti yang digunakan oleh pemeran/tokoh.

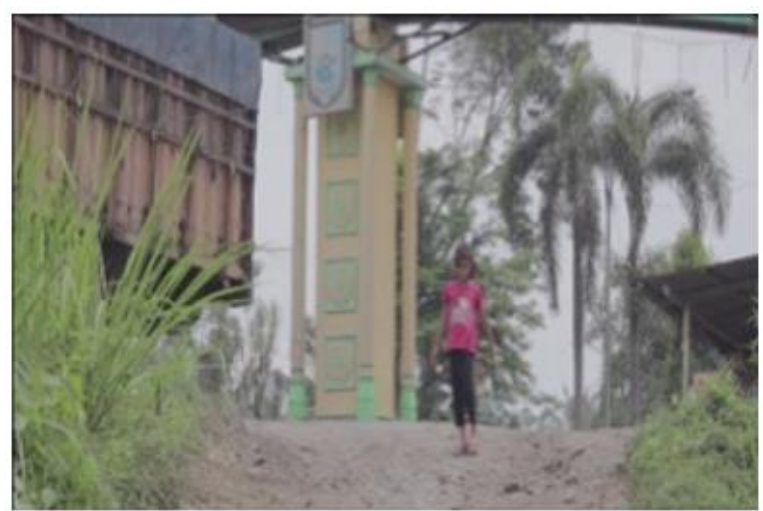

Gambar 6. Kostum Tokoh Inur (Screenshot Film "Dibalik Sungai Ular") (Wahyuni, 2020)

Sedangkan make-up yang digunakan pada tokoh yang terdapat pada film "Dibalik Sungai Ular" seperti tokoh Inur, ibu Marni, tetangga dan teman-teman Inur menggunakan make-up natural yang bermaksud untuk menjelaskan konsep realism atau normal seperti halnya
Gorga : Jurnal Seni Rupa

Volume 10 Nomor 01 Januari-Juni 2021

p-ISSN: 2301-5942 | e-ISSN: 2580-2380

kehidupan sehari-hari yang di tampilkan pada film tersebut.

\section{(3). Pencahayaan}

Unsur pencahayaan yang digunakan pada film "Dibalik Sungai Ular" banyak menggunakan pencahayaan alami dengan menggunakan bantuan cahaya matahari karena adegan yang terdapat pada film ini memang kebanyakan disetting waktu mulai siang ke sore hari. Penyajian adegan flasback juga lebih banyak adegan di siang hari.

Selain itu, pencahayaan pada film di balik sungai ular digunakan sebagai pembentuk suasana (mood) seperti terlihat pada gambar berikut ini:

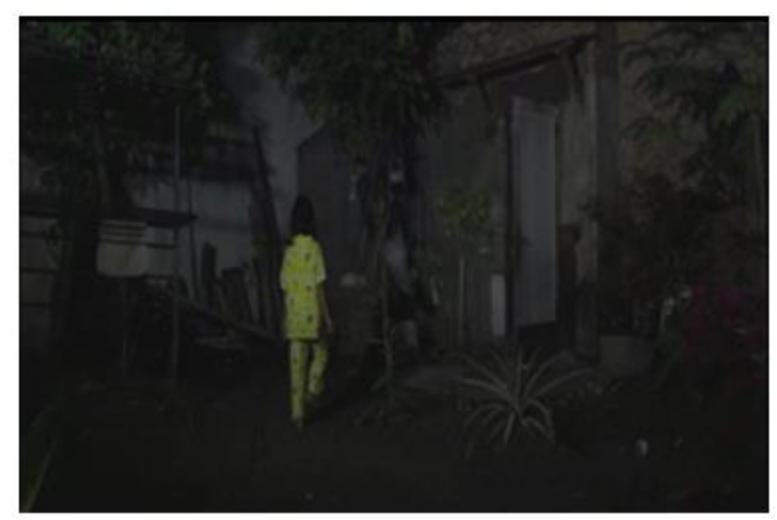

Gambar 7. Inur Ngelindur dan Pindah Tidur ke Tetangga (Screenshot Film "Dibalik Sungai Ular")

(Wahyuni, 2020)

Pada gambar 6 di atas terlihat film "Dibalik Sungai Ular" juga menggunakan pencahayaan buatan untuk menambah kesan larut malam pada gambar tersebut.

\section{(4). Pemain dan Pergerakannya}

Dalam proses pengadeganan, sutradara memiliki peranan penting dalam mengarahkan para pemain. Hal ini dilakukan agar adegan yang ditampilkan pada film terlihat natural. Pelaku cerita yang akan memotivasi naratif sehingga cerita selalu bergerak dalam melakukan sebuah aksi.

Inur sebagai tokoh utama membuka adegan cerita dengan posisi tertidur dengan kepala tergeletak di atas meja dan buku. Tindakan dari tokoh Inur menimbulkan aksi dan memacu cerita untuk bergerak maju ke depan. Pada adegan tersebut terdapat pola non-linear yang membiarkan penonton menduga-duga mengenai adegan selanjutnya. 

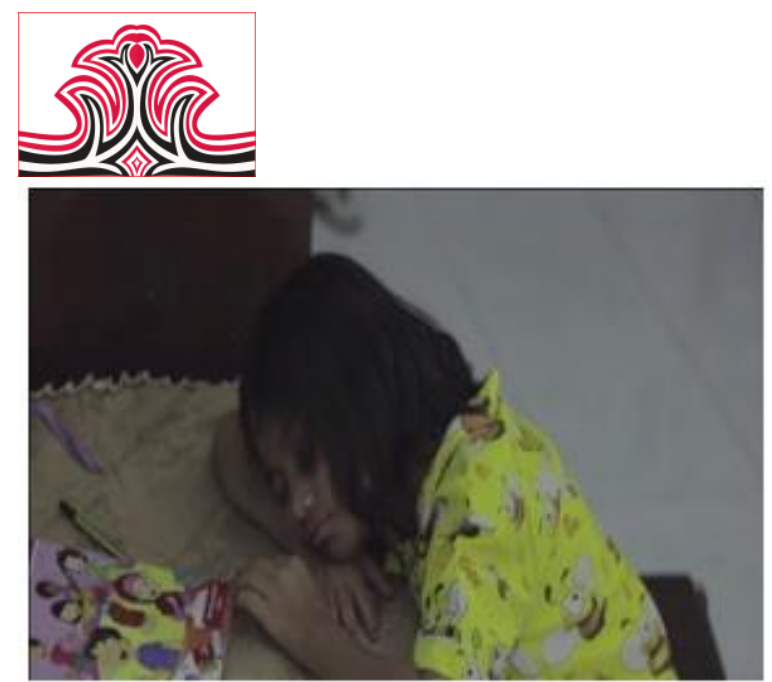

Gambar 8. Inur Ketiduran

(Screenshot Film "Dibalik Sungai Ular")

(Wahyuni, 2020)

Pola non-linear di awal adegan justru merupakan jawaban mengapa Inur dilarang kedua orang tuanya untuk bermain ke sungai lagi. Selain Inur tokoh ibu juga memiliki peran penting yang turut mendorong cerita dalam menimbulkan aksi ketika peran ibu mengatakan kepada Inur bahwa Inur tidak boleh pergi ke sungai lagi yang menimbulkan konflik antara Inur dan Ibu. Menurut Haig P. Manoogian alur cerita (plot) adalah penjabaran dari cerita sebuah film, terdiri dari rentetan kejadian bermotivasi dan berhubungan sebab akibat. Struktur menunjuk kepada kejadian-kejadian dari plot tersebut (Paransi, 2005: 8). Keterkaitan alur cerita memunculkan akibat aksi, tindakan dari pelaku cerita yang memotivasi terjadinya kesatuan peristiwa pada film "Dibalik Sungai Ular".

\section{5). Konsep Penyuntingan}

Konsep penyuntingan gambar pada film "Dibalik Sungai Ular" menggunakan teknik jump cut. Teknik jump cut digunakan untuk memperlihatkan lompatan pada adegan flashback saat pergantian shot. Kesinambungan waktu tersebut terputus karena lompatan yang lain berbeda waktunya sehingga penonton dapat membedakan adegan-adegan flashback.

Pada film "Dibalik Sungai Ular" teknik jump cut digunakan di beberapan scene mulai dari ketika pembukaan adegan awal dan ketika adegan mengingat dan mencari jawaban mengapa dilarangnya dirinya ke sungai. Seperti gambar berikut ini:
Gorga : Jurnal Seni Rupa

Volume 10 Nomor 01 Januari-Juni 2021

p-ISSN: 2301-5942 | e-ISSN: 2580-2380
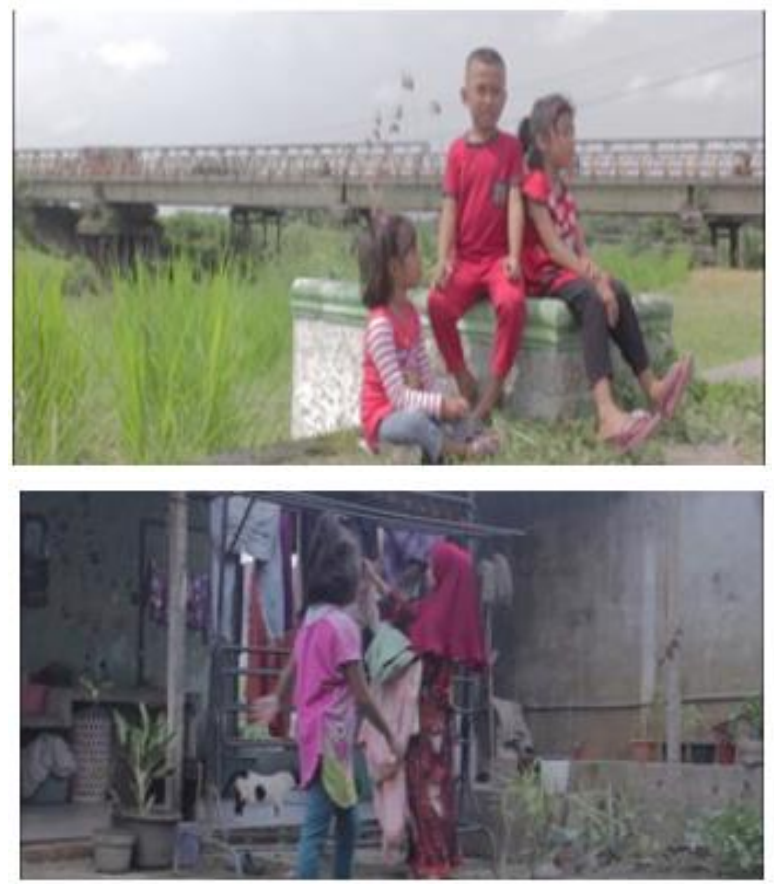

Gambar 9. Penerapan Teknik Jump Cut pada Adegan Inur Mengingat (Screenshot Film "Dibalik Sungai Ular") (Wahyuni, 2020)

Selain proses analisis di atas, penciptaan dari Film "Dibalik Sungai Ular" meliputi tahapan-tahapan seperti Pra Produksi, Produksi dan Pasca Produksi yang selanjutnya akan dijelaskan sebagai berikut:

\section{(1). Pra Produksi}

Praproduksi merupakan tahapan utama dalam produksi film dibuat. Tahap praproduksi dimulai dari merekrut pemain dan kru film yang terlibat, riset lokasi, mengedit naskah final dan membuat tujuan jangka panjang (Cheng, 2014: 5).

Tahap praproduksi proses penciptaan film "Dibalik Sungai Ular" memerlukan waktu yang cukup panjang dimulai dari merekrut pemain film dan crew film, antara lain adalah sebagai berikut:

Adapun Crew Film "Dibalik Sungai Ular" yaitu :

a. Produser : Surya Darma, S.Kom., M.Sn

b. Sutradara : Sri Wahyuni, S.Kom., M.Sn

c. Asisten Sutradara : Rara Essy

d. Direct of Photography: Nurhanifah Lubis

e. Cameramen dan Editor: Mhd. Ade Mulya

f. Tata Artistik : Muhammad Ramadani

g. Audio : Indriani

h. Clapper: Yara Murji'zah

i. Lighting : Fachreza Aditya Putra

Sedangkan untuk talent film "Dibalik Sungai Ular" yaitu:

a. Nurul Mardiana as Inur 


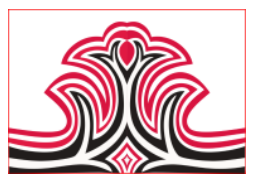

b. Selvi Maharani as Teman Inur 1

c. Raihan Pratama as Teman Inur 2

d. Lola Anggita as Ibu Inur

e. Muhasta as Bapak Inur

f. Indriani as tetangga

Setelah Penetapan dan pemilihan pemain film dan kru tersebut didapat, proses selanjutnya yaitu breafing dan reading naskah yang selanjutnya ketahap proses terjun lapangan. Berikut merupakan proses breafing dan reading proses penciptaan film "Dibalik Sungai Ular".

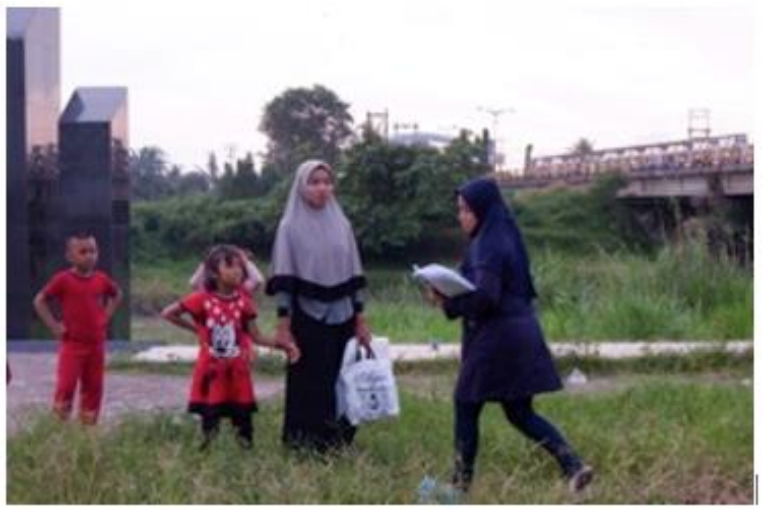

Gambar 10. Breafing dan Reading Naskah (Screenshot Film "Dibalik Sungai Ular") (Wahyuni, 2020)

Pemilihan lokasi juga menjadi pertimbangan dalam proses penciptaan film "Dibalik Sungai Ular". Lokasi yang menjadi titik utama pada saat proses produksi tepatnya di Jl. Medan - Tebing Tinggi, Simpang Tiga Pekan, Desa Citaman Jernih, Kec. Perbaungan, Kabupaten Serdang Bedagai, Sumatera Utara. Berikut merupakan view dari titik utama proses penciptaan film "Dibalik Sungai Ular".

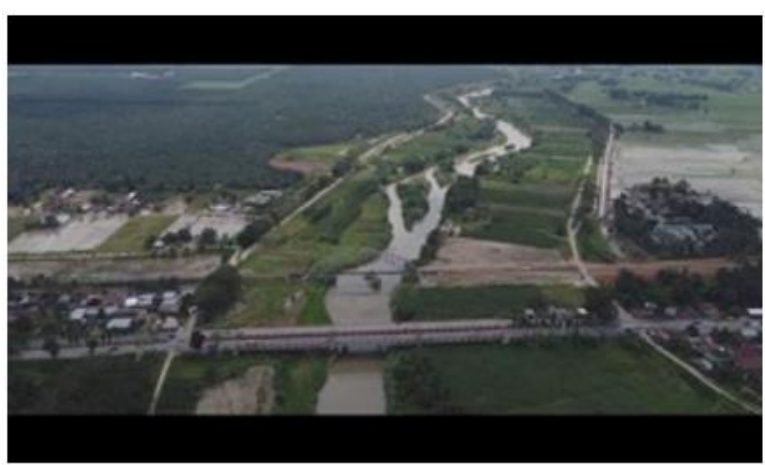

Gambar 11. View Sungai Ular (Screenshot Film "Dibalik Sungai Ular") (Wahyuni, 2020)

Tujuan jangka panjang yaitu memperkirakan bagaimana proses penciptaan film "Dibalik Sungai Ular" dapat terlaksana dengan baik, dengan mempersiapkan segala kebutuhan proses penciptaan "Dibalik Sungai Ular" dan persoalan administrasi
Gorga : Jurnal Seni Rupa

Volume 10 Nomor 01 Januari-Juni 2021

p-ISSN: 2301-5942 | e-ISSN: 2580-2380

untuk kemajuan proses penciptaan film "Dibalik Sungai Ular”.

Peralatan yang digunakan dalam tahapan ini menggunakan 2 jenis kamera Canon 700D, dan Canon 750D, Drone DJI Mavic Mini, dengan alat bantu lighting, tripod, reflector, Microphon Boya M1, dengan proses editing menggunakan laptop Asus X454Y, Prosesor : Amd A8, Vga : Radeon, Ram : 12GB, Hdd : 500GB, Ssd : 500Gb.

\section{(2). Produksi}

Tahap produksi adalah tahapan dimana proses perekaman dan syuting dilakukan. Pada tahap ini menginterpretasikan proses penciptaan film "Dibalik Sungai Ular" dengan kesesuaian naskah garapan film fiksi yang dibuat. Film fiksi terikat oleh plot. Dari sisi cerita, film fiksi sering mengunakan cerita rekaan di luar kejadian nyata serta memiliki konsep pegadeganan yang telah dirancang sejak awal. Struktur cerita film juga terikat hukum kausalitas. Cerita biasanya juga memiliki karakter protagonis dan antagonis, masalah dan konflik, penutupan, serta pola pembangunan cerita yang jelas. Film fiksi yang berada di tengah-tengah dua kutub, nyata dan abstrak, sering kali memikiki tendensi ke salah satu kutubnya, baik secara naratif maupun sinematik (Himawan Pratista, 2008: 4-8).

Proses produksi penciptaan film "Dibalik Sungai Ular" merupakan jenis film fiksi yang direpresentasikan menjadi suatu cerita karangan film yang saling berkesinambungan dengan $12 \mathrm{kru}$ yang memiliki tugas dan wewenang masing-masing dan 6 talent yang memiliki peran yang berbeda agar masing-masing kru dan talent memiliki tanggung jawab yang berbeda sehingga dapat menciptakan proses sebuah film dengan tujuan yang jelas. Berikut aktivitas proses penciptaan film "Dibalik Sungai Ular".

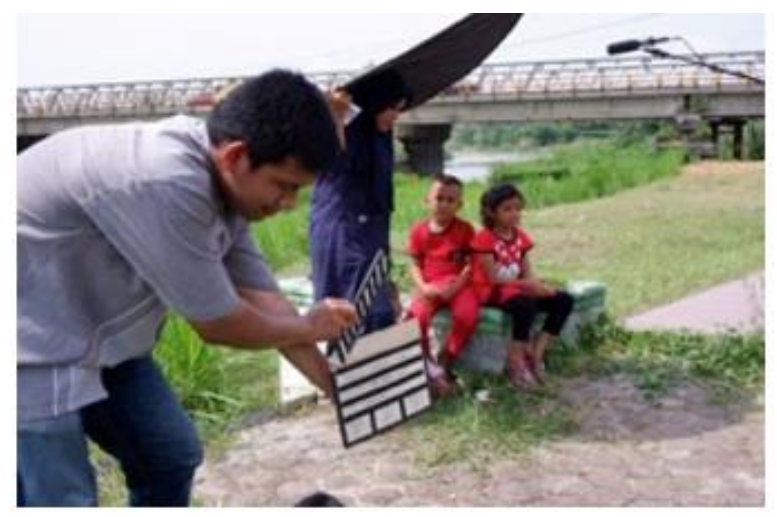

Gambar 12. Aktivitas Proses Penciptaan Film "Dibalik Sungai Ular"

(Screenshot Film "Dibalik Sungai Ular") (Wahyuni, 2020) 
Pengambilan gambar dilakukan dengan menggunakan dua jenis kamera (multi cam) dengan merk Canon 700D, dan Canon 750D, dan Drone DJI Mavic Mini sebagai alat bantu pertegas sinematografi. Berikut digambarkan pada proses penciptaan film "Dibalik Sungai Ular".

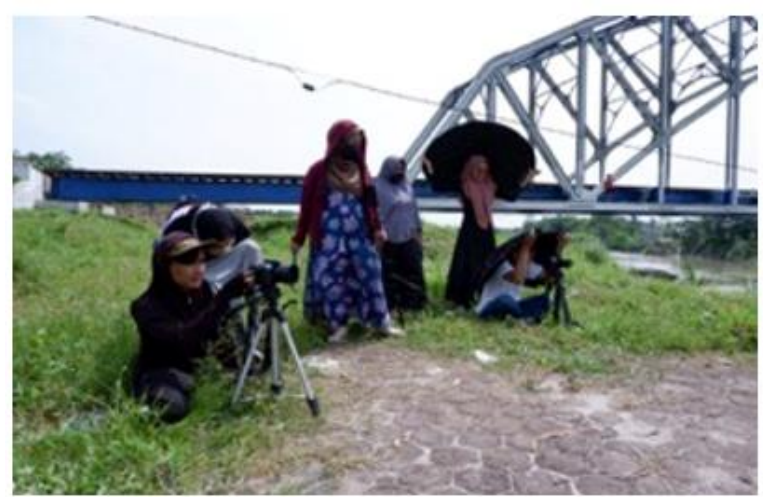

Gambar 13. Aktivitas Proses Penciptaan Film "Dibalik Sungai Ular" (Screenshot Film "Dibalik Sungai Ular")

(Wahyuni, 2020)

Proses produksi penciptaan film "Dibalik Sungai Ular" memiliki kendala yang dihadapi, sama halnya dengan yang dihadapi terhadap proses-proses film pada umumnya salah satunya yaitu proses pengulangan take yang menjadi kendala utama dikarenakan lupa adegan atau lupa dialog yang sering terjadi dan dialami oleh tiap-tiap talent, kemudian keterbatasan peralatan sehingga memaksimalkan fungsi dari alat-alat yang ada.

Pengambilan suara menggunakan Microphone Boya M1 dengan cara kerja terhubung menggunakan smartphone dalam proses produksi film "Dibalik Sungai Ular". Kendala teknis yang dialami adalah adanya gangguan (noise) pada proses pengambilan suara, hal tersebut dapat diminimalisir dengan menggunakan software Adobe audition yang dapat meredam sedikit noise. Berikut digambarkan pada proses penciptaan film "Dibalik Sungai Ular".

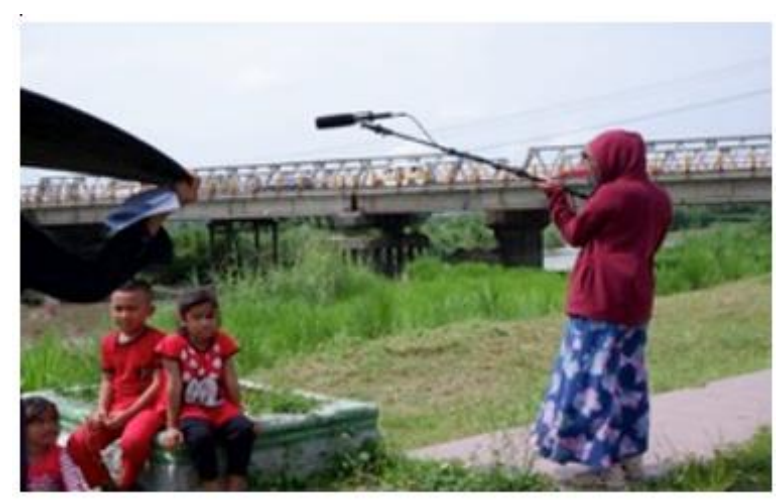

Gambar 14. Aktivitas Proses Penciptaan Film "Dibalik Sungai Ular"

(Screenshot Film "Dibalik Sungai Ular")

(Wahyuni, 2020)

Pada tahap penggunaan kamera menggunakan tone kamera cinestyle yang sebelumnya telah di instal pada perangkat kamera yang digunakan, sehingga memudahkan saat proses pengeditan dan memiliki kesan pertegas gambar yang bertujuan penyesuaian dengan film yang digarap, selanjutnya melalui proses pengeditan pertiap scene yang menjadi kesatuan yang utuh sehingga menciptakan film yang berkesinambungan yang dapat menciptakan kesan bagi penonton, hal tersebut tidak akan tercapai jika tidak adanya kekompakan dan komunikasi tim.

\section{(3). Pasca Produksi}

Pasca produksi atau Post produksi adalah tahap terakhir yang dilalui yaitu tahapan pemilihan gambar per tiap scene, suara dan efek visual ditambah, pengkoreksian dan penyelesaian film dilakukan pada tahap ini (Cheng, 2014: 6). Tahap pasca produksi merupakan tahapan yang dilalui dengan ketelitian salah satunya tahap editing. Tahap editing menggunakan menggunakan laptop Asus X454Y, dengan spesifikasi Prosesor : Amd A8, Vga : Radeon, Ram : 12GB, Hdd : 500GB, Ssd : $500 \mathrm{~Gb}$, dengan menggunakan software Adobe Priemiere Cc 2017. Pada tahap ini dilalukan dalam pemilihan pemotongan-pemotongan gambar atau scene-scene yang dipilih secara berkesinambungan sehingga membentuk kesatuan yang utuh.

Tahap pasca produksi melalui tahap yang cukup rumit sehingga membutuhkan ketelitian tingkat tinggi agar jalan cerita menjadi sinkron atau berkesinambungan dan cerita yang disajikan sesuai dengan yang diharapkan sutradara dengan tujuan terpenuhinya rasa puas penonton.

Tahap terakhir pada pasca produksi yaitu mengevaluasi hasil akhir yang didapat yaitu film "Dibalik Sungai Ular”, dalam tahap ini mengoreksi beberapa scene yang 
ditambah atau di cut sehingga menghasilkan film yang sesuai dengan tujuan yang diharapkan.

\section{KESIMPULAN DAN SARAN}

\section{Kesimpulan}

Penciptaan karya film "Dibalik Sungai Ular" mengaplikasikan melalui pendekatan konsep penyutradaraan alur non-linear. Penggunaan alur nonlinear dalam penciptaan film pastinya bukanlah hal yang baru, namun dalam film ini tentunya pengemasan film dibuat dengan cara yang berbeda agar lebih menarik penonton. Penerapan konsep penyutradaraan dengan alur non-linear dilakukan pada semua elemen mulai dari pra produksi (ide penciptaan hingga naskah), produksi (sinematografi dan mise en scene) dan pasca produksi (penyuntingan gambar). Dimana, proses tersebut guna untuk mempertegas ruang dan waktu dalam cerita film.

Sungai Ular memiliki banyak cerita-cerita mitos dan memiliki sejarah. Mitos yang berkembang mengenai sungai ular yaitu sungai ular dipercaya dihuni oleh sepasang buaya putih yang dapat merubah wujudnya menjadi manusia dan siap mencari mangsa dan menerkamnya. Selain itu, sungai ular memiliki cerita sejarah mengenai penjagalan para PKI atau sebagai salah satu lokasi perkubura masal para PKI.

Berangkat dari cerita di atas, sungai ular sangat menarik untuk di angkat menjadi sebuah film fiksi. Meskipun sungai ular memiliki cerita mitos dan sejarah dimasa lampau, namun film fiksi “ Dibalik Sungai Ular” tidak menceritakan secara spesifik sejarah-sejarah ataupun mitos tersebut. Melainkan penulis mengkemas film tersebut dengan versi yang berbeda yaitu dengan mengusung tema tentang seorang anak kecil dan keluarganya.

\section{Saran}

Pembuatan karya film fiksi "Dibalik Sungai Ular" tentunya tidak terlepas dari kekurangan, terlebih dalam hal teknis. Kendala teknis kerap kali ditemui pada saat proses produksi berlangsung hingga sampai penulisan ini selesai. Selain itu pada prosesnya, penciptaan karya film fiksi ini dilakukan ketika adanya pandemi yang terjadi di seluruh dunia termasuk Indonesia. Rencana proses produksi pun mundur beberapa kali karena melihat situasi yang kurang kondusif demi menjaga seluruh tim produksi tetap aman. Selain itu, persoalan teknis di lapangan juga kerap terjadi. Meskipun begitu karya film "Dibalik Sungai Ular" dapat terlaksana dengan lancar dan besar harapan penelitian ini dapat dikembangkan lebih lanjut oleh para seniman dan akademisi untuk lebih mengembangkan lagi kecerita yang lebih menarik tentunya.

\section{DAFTAR RUJUKAN}

Alfathoni, M. A. M. (2019). Mise En Scene dalam Film Lamaran Sutradara Monty Tiwa. PROPORSI: Jurnal Desain, Multimedia dan Industri Kreatif, 1(2), 165-178.

Sugiharti, A. (2016). PERANCANGAN BUKU MENGENAL DUNIA SENI RUPA UNTUK ANAK USIA DINI (Doctoral dissertation, Universitas Pendidikan Indonesia).

Andhika, Y. L. (2018). Film Bagurau; Representasi Citra Perempuan Minangkabau. Ekspresi Seni, 20(1),

56. https://doi.org/10.26887/ekse.v20i1.387

Cheng, T. (2014). Public relations and promotion in film: How it's done and why it's important.

Darmawan, H., \& Pramayoza, D. (2020). Abstrak. Gorga: Jurnal Seni Rupa, 09(1), 138-144. https://doi.org/10.24114/gr.v9i1.18359

Ediantes, E. (2016). Ritual Sebagai Sumber Penciptaan Film Basafa Di Ulakan. Ekspresi Seni: Jurnal Ilmu Pengetahuan dan Karya Seni, 18(1), 20-38.

Mawar Kembaren, M., Azharie Nasution, A., \& Husnan Lubis, M. (2020). Cerita Rakyat Melayu Sumatra Utara Berupa Mitos dan Legenda Dalam Membentuk kearifan Lokal Masyarakat. Rumpun Jurnal Persuratan Melayu, 8(1), 1-12. http://rumpunjurnal.com/jurnal/index.php/rumpu n/article/view/117

Peransi, D. A. (2005). Film/media/seni. Fakultas Film dan Televisi, Institut Kesenian Jakarta.

Pertiwi, G., \& Yusril, Y. (2019). Penciptaan Film Fiksi "Siriah Jadi Karakok" Dengan Fenomena Lesbian Di Sumatera Barat. Gorga: Jurnal Seni Rupa, 8(1), 192. https://doi.org/10.24114/gr.v8i1.13140

Pratista, H. (2008). Memahami film. Homerian Pustaka.

Si, N., Lajang, P., Cinta, C., Eks, P., Lajang, P., \& Utami, K. A. Y. U. (2017). UPT Perpustakaan ISI Yogyakarta. 1-22.

Sugiyono, P. (2011). Metodologi penelitian kuantitatif kualitatif dan R\&D. Alpabeta, Bandung. 